The author admires this potentate's pushfulness, and would welcome the advent of such another ruler, or a reincarnation of Chin, to awaken China from her sleep of ages-that is, Chin modernised and shorn of his wickedness. He may not have long to wait. Dr. Geil's historical notes on the life and doings of this famous emperor are written with force and an entertaining display of humour. But, after all, the manner of building, it is a sordid tale of suffering, of which the wall is a lasting memorial.

Dr. Geil pauses at intervals in his journey to copy ancient tablets of local wall interest, and to consider, at length, the myths and superstitions of the Chinese, and the condition of the world coeval with Chin the hero. The rise and progress of Genghis Khan, "the red raider,". who eventually pierced the barrier and conquered China, are dealt with. He is described as "A man of elemental fury beyond the sweep of twentieth century imagination," whose bloody career did of Europe and Japan urging forward the Chinese, aiding them in rearing a great wall of militarism more formidable than the barrier built by Chi-Hwangti to bar all foreign interference with the internal affairs of "The Central Flowery Land.'

In conclusion, this modern view of the Great Wall, with its wealth of illustrations, and the author's discussions over a wide field, should afford instruction and entertainment to the general reader. As a book of travels, further details regarding the route traversed would have been welcome.

J. T.

\section{DR. LUDWIG MOND, F.R.S.}

BY the death of $D_{1}$. Ludwig Mond this country has lost one of the most eminent of her chemical technologists, and the world is the poorer by the passing away of one who, himself a man of science of no mean attainments, gave liberally of the wealth

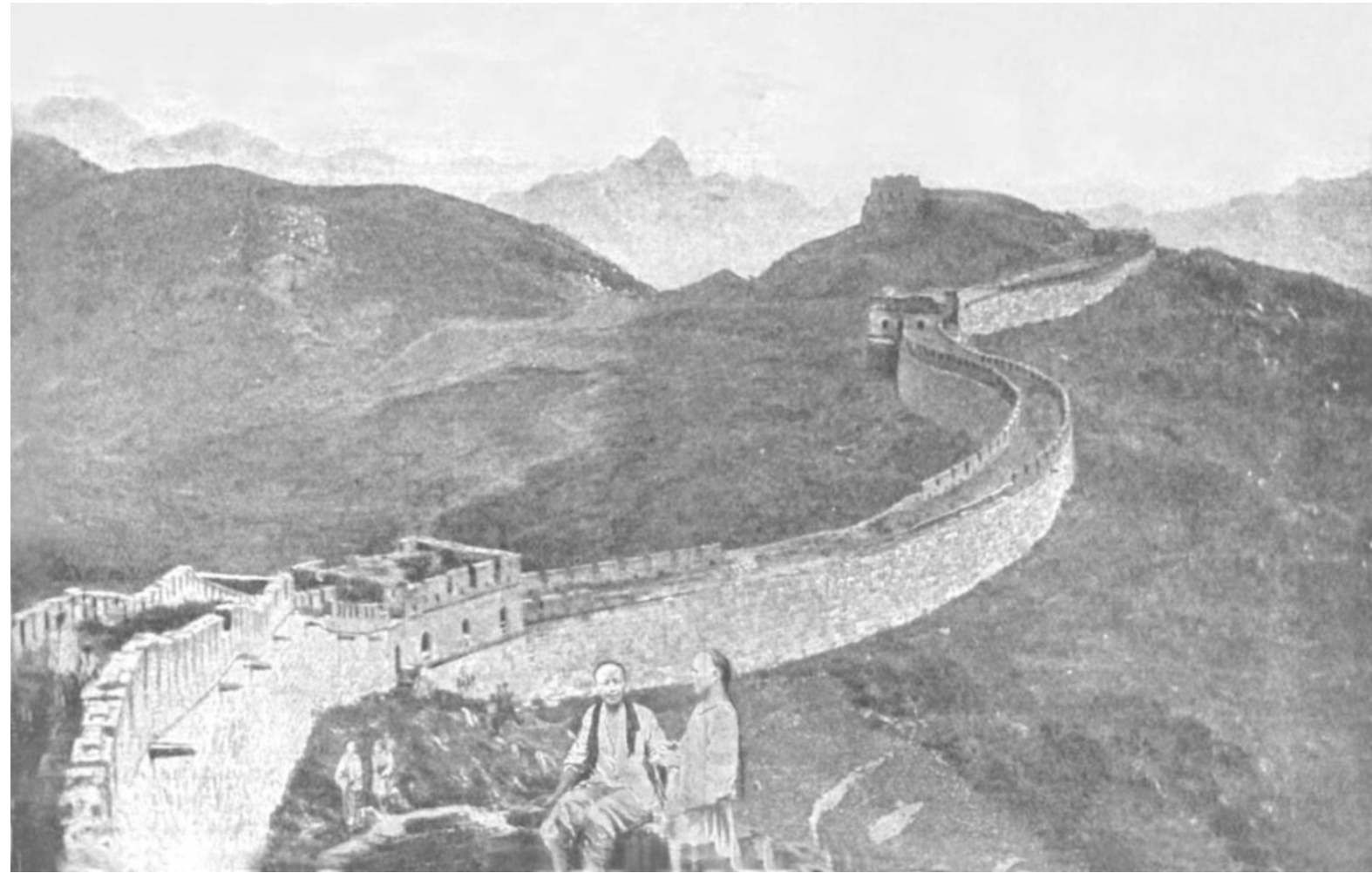

FIGr 2,-Lienhwacuih. From "The Great Wall of Chuna."

not end until he had slain as many people as now live in all New England, New York, and Pennsylvania-a monster of cruelty. Yet his grandson, Kublai Khan, who came to the throne, proved one of the most enlightened monarchs known to Chinese history. $\mathrm{He}$ excavated the Grand Canal, and extended his sway as far as Moscow and the Levant. Dr. Geil gives a brief résumé of mediæval China since the building of the wall to the present dynasty-the Manchu. $\mathrm{He}$ eulogises the good work done by the Christian missions, and hails the light of a reformation that in the future will make China a world Power of the first rank.

To anyone who knows the intellectual, as well as practical, potentialities of the Chinese, the eventual rise of this Yellow Peril seems far from impossible. Besides the missions of peace that are at work, there are other and rival missions from the armed camps which his knowledge and skill as a technologist brought him in order to promote the dignity and usefulness of science. Dr. Mond, as he would have been the first to admit, undoubtedly owed much to England, and he gave practical recognition of the extent of his indebtedness by the open-handed generosity with which during his life-time he supported and endowed her scientific institutions. $\mathrm{He}$ never forgot that it was through science he had prospered, and he was ever ready to return to the service of science a large measure of the riches she had conferred upon him.

The International Catalogue of Scientific Literature, and the establishment and endowment of the DavyFaraday Laboratory, are splendid monuments more enduring that brass. With these Dr. Mond's name will for ever be associated. But in reality they constitute only a fraction of the benefits he conferred upon

NO. 2095, VOL. 82] 
science, for there was hardly a single movement connected with the advancement or spread of physical science which did not find in him a generous and, at times, an enthusiastic and inspiriting supporter. In one other respect, too, his substance was always at the service of science. No appeal from those who enjoyed his confidence, or in whose judgment he had learned to trust, on behalf of the weak brother who had fallen by the wayside, was ever made in vain; and numberless acts of kindness, of sympathy, and of substantial help of which the world knows little or nothing, and of which even the recipients in many cases never knew the source, are recorded to his credit.

But it was not only by his wealth that Dr. Mond served science. In the organisation of science and in her councils he gave of his mental and intellectual powers with the same unstinted liberality that he gave of his material possessions. His knowledge and experience, his remarkable business aptitudes, his skill in the management of men, his faculty for organisation and direction, were freely at the service of every scientific society that had the good fortune to enlist his sympathy, or the wisdom to invite his cooperation.

Ludwig Mond was born in Cassel in 1839 , and, after having passed through the Polytechnic of his native place, he went to Marburg to study chemistry under Kolbe. Thence he repaired to Heidelberg to work under Bunsen, and to enjoy his full share of that alternation of study and play-each as strenuous as the other-which characterises the university life of that famous seat of learning. At Heidelberg he took his degree, and, attaching himself to technology, obtained situations in chemical works in Germany. At about this time he was attracted by a problem which had long baffled practical chemists, namely, the recovery of the sulphur employed incidentally in the Leblanc process in the conversion of common salt into soda, and which had passed from the oil of vitriol into the bye-product known as alkali-waste. He devised and patented a process for treating alkali waste, which, although long since superseded by others more economical in working, had a considerably measure of success for a time. He came to England with a view to the introduction of his method into the great alkali works of South Lancashire, Tyneside, and the Clyde district, and it was adopted by a number of manufacturers, notably in Widnes, in Newcastle, and by the Tennants of Glasgow. After a short stay in Holland, where he erected, and for a time managed, a factory to work the Leblanc process, he returned to this country and entered the chemical works of Hutchinson and Earle at Widnes.

Dr. Mond was then twenty-eight years of age. In the previous year he had married his cousin, Miss Frida Loewenthal, and he settled down in the most dismal of all the manufacturing towns in Lancashire with the intention of devoting his talents and energy to the business of manufacturing alkali and the other products commonly associated with it. At this period soda was exclusively made in this country by the Leblanc process, which involves the use of sulphuric acid and the production of large quantities of hydrochloric acid, as well as the formation of the alkali waste already referred to. Other processes had been suggested, and some had actually been brought into successful operation, as, for example, the cryolite process invented by Julius Thomsen, of Copenhagen, and worked so far back as 1857 . It was known that common salt might be changed to some extent into bicarbonate of soda by the action of carbonic acid in presence of ammonia. Dyar and Hemming had worked out a method based on this principle, but their efforts to compete with the Leblanc soda re- sulted in failure, and the firm was ruined. In theory the process was seductively simple, but all attempts to determine the practical conditions needed to ensure complete conversion were unavailing until the method was systematically investigated by two young Belgian chemical engineers, the brothers Solvay, who, in the early 'seventies, devised the modification of the Dyar and Hemming process which has since been known as the ammonia-soda or Solvay process.

Dr. Mond was afforded an opportunity of judging the practicability of the process as thus improved, and so sanguine was he of its commercial possibilities that he determined to embark his little capital in acquiring a licence to work the ammonia-soda process in England. He enlisted the sympathy of his friend Mr. J. T. Brunner (now the Right Hon. Sir John Brunner, Bart., M.P.) with the enterprise, and the result was the formation of the firm of Brunner, Mond and Co., who acquired the Winnington Hall estate, near Northwich, and erected their works over the Cheshire salt deposits. The success of this firm has been phenomenal, and to-day the Winnington works is one of the largest, if not actually the largest, manufactory of the kind in the world. Much of this success was due, in the outset, to the genius and inventive skill of Dr. Mond. In the beginning innumerable difficulties were met with. During the first twelve months, as Sir John Brunner recently said, everything that could explode exploded, and everything that would break broke, until the partners had little left but their credit and their licence from Ernest Solvay. Thanks in large measure to the energy and resourcefulness of Dr. Mond, these troubles were circumvented, and in a surprisingly short space of time the process became a magnificent success. Leblanc soda would have become a thing of the past had it not been for its bye-product, the hydrochloric acid, which alone saved it from extinction.

If the Leblanc process wasted its sulphur, the ammonia-soda process equally wasted its chlorine, and Dr. Mond made repeated attempts to remove this blot on the theoretical cycle of operations upon which the method is based. At one time it seemed as if success had attended his efforts, but the result showed that the economical production of bleaching powder from calcium chloride under existing conditions is a problem which still remains to be solved. Whether the ammonia-soda process has within it the basis of permanent success, time alone can show. As regards the production of ammonia and the means taken for its recovery and preservation, it is difficult to see where fresh economies are possible. In the meantime, new, or at least improved, sources of energy are rapidly becoming available, and every decade shows progress in the methods of transforming this energy into work. Dr. Mond himself devised plans for greatly augmenting its supply, and in the Mond gas there is a relatively cheap source of power which, while it may contribute incidentally to the supply of the all-essential ammonia, may indirectly undermine the stability of the very process with which his name is primarily and more particularly associated. The economical production of alkali from common salt by electrolytic methods in this country is largely a question of the transformation of the potential energy in coal into electrical power, and although theoretically a definite quantity of ammonia is capable of turning an indefinitely large quantity of salt into soda, this can only be effected by the expenditure of energy which itself costs money to produce and apply.

Dr. Mond had a remarkable aptitude for pushing his experimental inquiries into abstract fields of research, and for promptly turning the results to practical account. His discovery, in collaboration with NO. 2095, VOL. 82] 
Langer and Quincke, of an entirely new and altogether unlooked-for group of chemical compounds, now known as the metallic carbonyls, is an admirable illustration of this faculty. The formation of nickel carbonyl-a most interesting substance produced by the direct combination of carbon monoxide with nickel -led to the establishment by him of a new process for the extraction of the metal from its ores which is now in successful operation by the Mond Nickel Company at Swansea.

Dr. Mond was a well-read man of liberal culture and artistic tastes, broad-minded and tolerant, and of a judgment ripened by contact with leading men of all conditions and countries. His merits as a man of science and a technologist were widely recognised. $\mathrm{He}$ was an honorary graduate of universities at home and abroad; a Fellow of the Royal Society, and a member of the Accademia dei Lincei. He was president of the Society of Chemical Industry in 1889 , and of the chemical section of the British Association in 1896 . He was offered the presidency of the Chemical Society a year or so ago, a distinction he was unable to accept owing to the state of his health.

He died on December II, I909, in the seventy-first year of his age, and was buried at the St. Pancras Cemetery, East Finchley.

T. E. Thorpe.

We have received the following short statement of generous assistance afforded by Dr. Mond to the progress of science, in addition to the foundation and endowment of the Davy-Faraday Research Laboratory, of which we hope to give an account in another issue.

Dr. Mond did not restrict his benefactions in science to the direct encouragement of physical and chemical researches. He was an original member of the council of the British Institute of Preventive Medicine (which subsequently developed into the Lister Institute), and gave $2000 l$. towards its foundation in 1893 . $\mathrm{He}$ also, three years ago, furnished $500 \mathrm{l}$. for installing an apparatus for the investigation of caisson disease and of the problems of deep-sea diving. The work in connection with this investigation was carried on by Drs. Haldane and Boycott, and Lieut. Damant, and their results were published in the Journal of Hygiene, and in a report to the Admiralty. At Dr. Mond's suggestion, and with the aid of a subsidy from him, a research into the toxicology of nickel carbonyl, a substance he had himself discovered and put to practical use in the manufacture of pure nickel, was carried out by $\mathrm{H}$. W. Armit, who published the results in two papers in the Journal of Hygiene.

In the year 1904 Dr. Mond contributed Io,0oo lire towards the cost of erecting a laboratory and hostel at Col d'Olen in connection with the International Laboratory of Physiology on Monte Rosa, on the understanding that the Royal Society should have the permanent nomination to two posts in the laboratory.

Shortly after his election into the Royal Society in I89 I, he gave practical effect to the deep interest which he felt in scientific bibliography. Indeed, but for his generous and active cooperation it would probably have been impossible for the Royal Society to continue its great undertaking of publishing a catalogue and index of the scientific literature of the last century.

In the second year of his fellowship of the Society Dr. Mond made a donation of $2000 l$. towards the cost of preparing the remaining material of the Catalogue and Subject Index of Scientific Papers, of which the third series was then approaching completion; and at the same time gave a promise of further assistance. This promise was amply fulfilled. Ten years later, in 1902, when the task of dealing with the mass of material published in the last seventeen years of the nineteenth century had to be faced, Dr. Mond offered $6000 l$. in four yearly instalments of $\mathrm{I}_{500 l}$. for the purpose of the completion of the catalogue and of the index. Again, in Igo6, on the expiry of the four years, he gave a further $6000 l$. in three yearly instalments of $2000 l$. each for the same purpose; and, towards the end of the year I908, he promised an additional donation of $2000 l$., with the view of accelerating the publication of the catalogue, and more particularly of the three subject-index volumes for mechanics, physics, and chemistry.

Dr. Mond also took an active part in the inauguration of the International Catalogue of Scientific Literature, now in its seventh year of publication, and his interest in that undertaking continued unabated to the end of his life.

\section{SIR ALFRED JONES, K.C.M.G.}

$\mathrm{O}^{\mathrm{F}}$ all the "slings and arrows of outrageous fortune," I have not of ten experienced one sharper than the news of the death of Sir Alfred Jones. I am not sure that, broadly looked at, the loss of a battle would not have been more tolerable. For a defeat may be retrieved, but the loss of a commander may be irremediable.

This is to rate his loss pretty high, but not, I think, too much so. For the man was of a quality of which I have not met with the like in the past, nor do I expect to do so in the future. I cannot pretend that I knew him intimately, for he was of that Napoleonic sort which does not invite intimacy. But we were brought together by common interest in public work, where we each strove strenuously by different paths, and where success attended Jones more than could have been hoped for.

Part of the story is told admirably by a sympathetic hand in the Times. If I lift the veil a little further, the official indiscretion, if it be such, must be condoned in justice to Jones's memory. An old-fashioned firm, Elder, Dempster and Co. were the shipping agents of Kew in Liverpool. They carried on the trade with the West African colonies which has always been centred there; and in this firm Jones was originally a clerk.

But at the start these colonies were mere trading settlements on the coast which no one at home troubled about so long as they did not trouble. Then came the partition of Africa; the hinterlands were brought under British control, and a new problem immediately arose. If tribal wars are to cease, and an orderly government is to be maintained, a revenue to support it must be raised; and in the last resort this can only be achieved by the promotion of native agriculture and the supply of produce for an export trade.

With these ends in view, Kew succeeded in establishing a number of cheap botanical stations, where plants suitable for cultivation could be grown and propagated, and where the natives could learn cultural methods by inspection. The attempt, for the most part, was rather acquiesced in than encouraged by the colonial officials on the spot, and Jones was perhaps the first to impress spontaneously upon the Colonial Office its importance. He had by that time grasped the future of West Africa, had bought out his old masters, and placed West African trade on an entirely new footing. Incidentally he restored prosperity to the Canaries, and introduced the banana into England. Amongst the principal products of West Africa are various sorts of oil-seeds; for these Liverpool was hardly more than an entrepot, as their principal market was in France. To utilise them at home, Jones started large oil-mills, All this, so far

NO. 2095, VOL. 82] 